\title{
Review of the Level of Awareness' Towards Occupational Hazards among Orthodontic Staff at Selected Dental Clinics, Saudi Arabia
}

\author{
Naif Mayouf Alrasheedi \\ General Dentists, PHC Buraydh, Saudi Arabia
}

\begin{abstract}
Background: Notwithstanding the highlighting on patient safety in dental clinics, Number of hours a dentists works directly affects his health, especially the strained posture the dentist is in despite the fact that treating a patient, which causes anxiety on the spine and limbs and is a major cause for musculoskeletal problems that dentists face. Based on evidence, Majority of the dentists had stress while working on patients. Various clinical procedures such as unanticipated emergency situations, anesthetization of patients, if the patient is not satisfied with the treatment, and unskillful treatment planning contribute to development of situations, which lead to high blood pressure, fatigue, tiredness, and increased stress. Objective: To assess the level of awareness' towards occupational hazards among orthodontic staff at the selected dental clinics, Saudi Arabia. Method: A cross-sectional survey was conducted at five dental clinics, Saudi Arabia. Forty Two items of self-administered questionnaire was provided to 250 orthodontic staff in the research setting based on their area of their specialties to assess the level of awareness' towards occupational hazards among orthodontic staff at the selected dental clinics, Saudi Arabia. Results: This study finding showed that awareness towards Occupational Hazards among some orthodontic staff at dental clinics was variable. The majority (87.6\%) of the orthodontic staff had a high level of awareness towards Occupational Hazards in relation to Hazards due to Nitrous Oxide Gas. Furthermore, orthodontic staff had a high level of awareness towards Occupational Hazards in relation to Infection (85.6\%). On the other hand (66.4\%) of the orthodontic staff had a lowest level of awareness towards Occupational Hazards in relation to Stress. Although, concerning the Intermittent Level of Awareness the highest level was awareness towards Occupational Hazards in Occupational in the item Nervousness and anxiety after Work (79.2\%). Conclusions: The current study results revealed that there were high levels of awareness among the orthodontic staff towards occupational hazards within the study setting.
\end{abstract}

Keywords: Occupational Hazards; Awareness review \&Orthodontic staff

\section{Introduction}

Review of literature documented that, The main clinical applications of lasers in dentistry which include Soft tissue , periodontal surgery, Root canal treatment, Desensitization Analgesia, Endodontic, Tooth bleaching and Tooth cavity preparation .The main occupational hazards associated with the use of lasers as Eye damage, Skin damage, Fire and Smoke inhalation (cellular and viral debris). (Pournaras, 2004).

According to Ayatollahi, (2012), 83\% of dentists believe dentistry is "very stressful", with nearly $60 \%$ believing that dentistry is more stressful than other professions. Some of the main sources of stress in dentistry include Overcoming pain, Fear, Administration of anesthesia, Patient dissatisfaction with treatment, Running behind schedule , Work-life balance \& "Techno-stress"

Professional risk factors in dentistry may harm dentists and their team. Despite numerous technical advances in recent years, many occupational health problems still persist in modern dentistry. These include exposure to infectious diseases, radiation, dental materials, and noise; musculoskeletal disorders; dermatitis and respiratory disorders; eye injuries; and psychological problems. It is essential for an orthodontist to recognize these risk factors and protect against them. The scientific and clinical literature on occupational hazards in orthodontics is reviewed to identify and recognize the risks, new guidelines, precautions and protocols are rapidly instituted to greatly reduce or even eliminate the occupational hazard. (Rapiti, et al., 2005)

Gambhir, R. S. (2011), mentioned that, hazards caused by non adherence to universal precautions by the health care providers, statistics reported by the Central Register of Occupational Diseases in Poland indicates that among 314 new cases of occupational diseases in HCWs in 2005, HBV and $\mathrm{HCV}$ represented $42.6 \%$ of all cases.9 Despite the substantial reduction in HBV infection since vaccination was introduced in 1989, the incidence of HCV hepatitis in Poland is still on the increase in this occupational group.

Dental care professionals are at risk for occupational exposure to a variety of hazardous chemicals and situations. Being unaware of the potential hazards in the work environment makes them more vulnerable to hazards. Furthermore, Orthodontic staff should have a high level of awareness about occupational hazards enhance consciousness education has not been prominent among dentists. To the maximum of understanding, the special treatment of orthodontic staff in relation to knowledge and awareness about policies of safety measures within the work setting. Consequently, conducted this study to assess the level of awareness' towards occupational hazards among orthodontic staff at the dental clinics, Saudi Arabia.

\section{Participants and Methods}

This study was conducted with orthodontic staff at the selected dental clinics, Saudi Arabia. The study was granted ethical approval by the clinics ethical committee.

\section{Volume 6 Issue 12, December 2017}




\section{International Journal of Science and Research (IJSR) \\ ISSN (Online): 2319-7064}

Index Copernicus Value (2013): 6.14 | Impact Factor (2015): 6.391

The participants were selected from the selected dental clinics. After signing an informed written consent form, the questionnaire was given to each participant. Before administration of the questionnaire, the purpose of the study was explained to each respondent and confidentiality of the information guaranteed.

The research was carried out by one of the authors who were appropriately trained in administering the informed consent and the self-report questionnaire to the participants. In this cross-sectional study, a structured questionnaire prepared by the authors, was administered to the participants .Forty Twoitem self-administered structured questionnaire about awareness' towards occupational hazards among the selected orthodontic staff, who advised de novo and tested.

It included a full range of response options, designed to identify the practitioner's level of to assess their level awareness' towards occupational hazards among orthodontic staff within the selected setting. Prior to distribution of the questionnaire, a pilot study was done on a selective group of health care workers who were asked to fill out the questionnaire and return it back with their remarks and criticism. Minor changes were then made to the final tool.

The questionnaire consisted of demographic information such as occupation, age, gender, and the marital status. The second part of the questionnaire comprised of questions regarding their level of awareness' towards occupational hazards among medical staff. This part also assessed awareness' towards occupational hazards. It took approximately 30 minutes to complete each appraisal.

The level of awareness' towards occupational hazards among orthodontic staff among orthodontic staff at the dental clinics, Saudi Arabia. By examining questions. A score of " 1 " was assigned for a correct answer and " 0 " for an incorrect answer. A health care worker who obtained a total score of "5" was considered "very aware;" "4 or 3" "somewhat aware;" and "1 or 0" "not aware."The data were coded and analyzed by SPSS $®$ for Windows ${ }^{\circledR}$ ver. 12.0. Strict confidentiality was maintained. All the data were stored in computers at a secured location, with access provided only to the researchers involved in the study. The $\chi 2$ test was used to test association between categorical variables. A p value $<0.05$ (two-tailed) was considered statistically significant differences.

\section{Results}

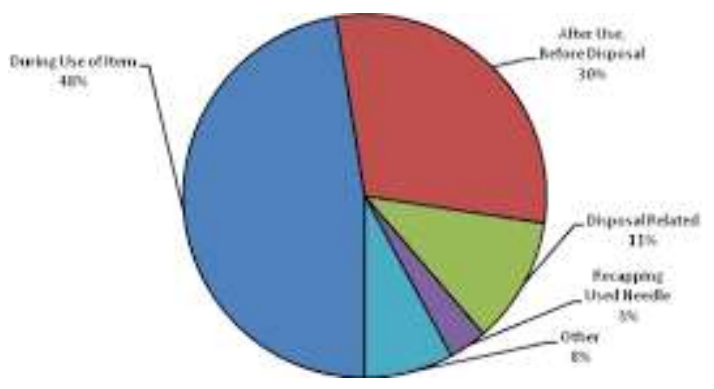

Level of Awareness' towards Occupational Hazards among Orthodontic staff at the Selected Clinics

\begin{tabular}{|c|c|c|c|c|c|c|}
\hline \multirow{2}{*}{ Items of Occupational Hazards } & \multicolumn{2}{|c|}{ High Level of Awareness } & Intermittent Level of Awareness & \multicolumn{2}{c|}{ Low Level of Awareness } \\
\cline { 2 - 7 } & No & $\%$ & No & $\%$ & No & $\%$ \\
\hline Latex Hypersensitivity & 200 & $80.0 \%$ & 10 & $4.0 \%$ & 40 & $16.0 \%$ \\
\hline Musculoskeletal Disorders & 202 & $80.8 \%$ & 18 & $7.2 \%$ & 30 & $12.0 \%$ \\
\hline Hazards due to Nitrous Oxide Gas & 219 & $87.6 \%$ & 11 & $4.4 \%$ & 20 & $8.0 \%$ \\
\hline Percutaneous Exposure Incidents & 204 & $81.6 \%$ & 6 & $2.4 \%$ & 40 & $16.0 \%$ \\
\hline Nervousness and anxiety after Work & 198 & $79.2 \%$ & 22 & $8.8 \%$ & 30 & $12.0 \%$ \\
\hline Infection & 214 & $85.6 \%$ & 14 & $5.6 \%$ & 22 & $8.8 \%$ \\
\hline Stress & 166 & $66.4 \%$ & 24 & $9.6 \%$ & 60 & $24.0 \%$ \\
\hline
\end{tabular}

This study finding showed that awareness towards Occupational Hazards among some orthodontic staff at dental clinics was variable. The majority $(87.6 \%)$ of the orthodontic staff had a high level of awareness towards Occupational Hazards in relation to Hazards due to Nitrous Oxide Gas. Furthermore, orthodontic staff had a high level of awareness towards Occupational Hazards in relation to Infection $(85.6 \%)$.On the other hand $(66.4 \%)$ of the orthodontic staff had a lowest level of awareness towards Occupational Hazards in relation to Stress. Although, concerning the Intermittent Level of Awareness the highest level was awareness towards Occupational Hazards in Occupational in the item Nervousness and anxiety after Work (79.2\%).

\section{Discussion}

This study finding showed that awareness towards Occupational Hazards among some orthodontic staff at dental clinics was variable. The majority $(87.6 \%)$ of the orthodontic staff had a high level of awareness towards Occupational Hazards in relation to Hazards due to Nitrous Oxide Gas. Furthermore, orthodontic staff had a high level of awareness towards Occupational Hazards in relation to Infection $(85.6 \%)$.On the other hand $(66.4 \%)$ of the orthodontic staff had a lowest level of awareness towards Occupational Hazards in relation to Stress. Although, concerning the Intermittent Level of Awareness the highest level was awareness towards Occupational Hazards in

Occupational in the item Nervousness and anxiety after Work $(79.2 \%)$

It was surprising the majority of the staff who handled mercury were unaware they could be exposed to chronic mercurial poisoning. All dental personnel should be alerted of the risk of mercurial poisoning and should be familiar with the preventive measures provided by the FDI against mercurial poisoning. It is advisable to conduct regular mercury vapor level assessments in clinical settings; receive episodic individual amalgam blood level tests; and use

\section{Volume 6 Issue 12, December 2017




\section{International Journal of Science and Research (IJSR) \\ ISSN (Online): 2319-7064}

Index Copernicus Value (2013): 6.14 | Impact Factor (2015): 6.391

goggles, water spray, and suction during the removal of old amalgam restorations.

This study has shown the majority of the staff were aware of the risk of injuries from sharps and needles which is rated to have high occurrence among health workers at least in the United States. In this study, health care workers employed in the health sector for longer periods were more aware of universal precautions compared with those who served for shorter periods. Training and education have been found to be of paramount importance to developing awareness among health care workers, as well as improving adherence to highquality clinical practice. This research findings is congruent with the findings of the study carried out by (Rapiti, et al., 2005), who found that he greater awareness of universal precautions among health care workers employed for a longer period non-compliance among medical doctors and nurses are associated with insufficient knowledge, workload, forgetfulness, workplace safety and the insight that colleagues also failed to track.

Personnel protective equipments reduce the risk of exposure of the health care provider's skin or mucous membranes to potentially infectious materials. Protective barriers reduce the risk of exposure to blood and other body fluids to which universal precautions apply. Examples of protective barriers include gloves, gowns, masks, and protective eyewear. Just over one half of the respondents indicated that they were provided with protective equipment most times. Furthermore, more nurses were provided with protective equipment than medical technologists and medical doctors. Interestingly, more respondents who were aware of universal precautions reported being provided with protective equipment more often than those who were somewhat or not aware. This study results congruent with the research data carried out by Pournaras, et al,2004, who reported that less than two-thirds of health care workers claimed that they always used personal protective equipment such as aprons, gowns and gloves, during surgeries and while conducting deliveries. According to Jawaid, et al, among medical doctors working in a tertiary care hospital in Pakistan, compliance for hand washing was $86 \%$, for wearing gloves was $79 \%$, masks $46 \%$, eye goggles $25 \%$ and for using gowns/plastic aprons was $45 \% .35$ However, there is sometimes a high rate of non-compliance among health care workers and this may be due to a lack of understanding among health care workers of how to properly use protective barriers.

This study showed that there was high level of awareness' towards occupational hazards among orthodontic staff within the study setting. These findings suggest that training of dental staff to maintain and enhance their knowledge about occupational safety, blood borne pathogens and universal precautions could improve their use of universal precautions. Regular training should include the universal precautions, initial biohazard handling, safety policies, safety behavior, safety equipments, continuing monitoring and maintain continuous quality improvement concerning the practice of occupational safety.

\section{Acknowledgements}

Appreciation is hereby extended to all the participants and administrators staff at the selected dental clinics-Saudi Arabia.

\section{References}

[1] Ayatollahi, J. (2012). Occaptional hazards to Dental staff. Dental Research Journal, 8. British Dental Association. (2004).

[2] Health \& Safety Law for Dental Practice. London: BDA. British Dental Association. (2009). Infection Control in Dentistry. BDA. Dental Council of Ireland. (2015). Code of Practice Relating to: Infection prevention and control. Dublin: Dental Council.

[3] European Commission. (2003). Radiation Protection: The status of the radiation expert in the EU member states and applicant countries; study on education and training in radiation protection.

[4] Gambhir, R. S. (2011).Occupational Health Hazards in current Dental Profession - A Review. The Open Occupational Health \& Safety Journal, 8. Government of Alberta. (2011).

[5] Handbook of Occupational Hazards and Controls for Dental Workers. Health \& Safety Executive. (2012). Safety Requirements for Autoclaves. HSE. International Standards Organisation. (2009).

[6] Dentistry - Information System on the Location of Dental Equipment in the Working Area of the Oral Healthcare Provider. Epidemiology and Infection Journal. 2003, 122: 259-65. $10.1017 / \mathrm{S} 0950268899002186$.

[7] National Health Service Estates. (n.d.). Oral Surgery Orthodontics Restorative Dentistry. HMSO.

[8] Regina Chan, Molassiotis Alexander, Eunica Chan, Virene Chan, Becky Ho, Chit-Ying Lai, et al: Nurses' knowledge of and compliance with universal precautions in an acute care hospital. International Journal of Nursing Studies. 2002, 39: 57-63.

[9] Pournaras S, Tsakris A, Mandraveli K, Faitatzidou A, Douboyas J, Tourkantonis A: Reported needlestick and sharps injuries among healthcare workers in a Greek general hospital. Occupational Medicine. 2004, 7: 4236. 10.1093/occmed/49.7.423.

[10] Lacerda RA. Infeccao hospitalar e sua relacao com a evolucao das practicas de assistencia a saude. In: Lacerda RA, ed. Controle de infeccao em centro cirurgico. Sao Paulo: Atheneu, 2003: 9-23.

[11] Lacerda RA, Egry EY. As infeccoes hospitalares e a sua relacao com o desenvolvimento da assistencia hospitalar: reflexoes para analise praticas atuais de controle. Rev Latinoam Enfermagem 1997;5:13-23.

[12] Beltrami EM, Williams IT, Shapiro CN, Chamberland ME. Risk and management of blood-borne infections in health care workers. Clin Microbiol Rev 2000;13(3):385-407.

[13] Gerberding JL. Incidence and prevalence of human immunodeficiency virus, hepatitis B virus, hepatitis C virus, and cytomegalovirus among health care 


\section{International Journal of Science and Research (IJSR) \\ ISSN (Online): 2319-7064}

Index Copernicus Value (2013): 6.14 | Impact Factor (2015): 6.391

personnel at risk for blood exposure: final report from a longitudinal study. J Infect Dis 1994;170(6):1410-7.

[14] Ruben FL, Norden CW, Rockwell K, Hruska E. Epidemiology of accidental needle-puncture wounds in hospital workers. Am J Med Sci 1983;286(1):26-30.

[15] Pruss-Ustun A, Rapiti E, Hutin Y. Estimation of the global burden of disease attributable to contaminated sharps injuries among health-care workers. Am J Ind Med 2005;48(6):482-90.

[16] Khuri-Bulos NA, Toukan A, Mahafzah A, et al. Epidemiology of needlestick and sharp injuries at a university hospital in a developing country: a year prospective study at the Jordan University Hospital, 1993 through 1995. Am J Infect Control 1997;25(4):322-9.

[17] Wang FD, Chen YY, Liu CY. Analysis of sharpedged medical-object injuries at a medical center in Taiwan. Infect Control Hosp Epidemiol 2000;21(10):656-8.

[18] Pruss-Ustun A, Rapiti E, Hutin Y. Sharp injuries: global burden of disease from sharp injuries to health care workers Geneva, Switzerland. World Health Organization, 2003.

[19] Orji EO, Fasubaa OB, Onwudiegwu U, et al. Occupational health hazards among health care workers in an obstetrics and gynaecology unit of a Nigerian teaching hospital. J Obstet Gynaecol 2002;22(1):75-8.

[20] Recommendations for protection against viral hepatitis. MMWR Morb Mortal Wkly Rep 1985;34(22):313-24, 329-35.

[21] Recommendations for preventing transmission of infection with human T-lymphotropic virus type III/lymphadenopathy-associated virus in the workplace. MMWR Morb Mortal Wkly Rep 1985;34(45):681-6, 691-5.

[22] McCarthy GM. Universal Precautions J Can Dent Assoc 2000;66:556-7.

[23] Update: human immunodeficiency virus infections in health-care workers exposed to blood of infected patients. MMWR Morb Mortal Wkly Rep 1987;36(19):285-9.

[24] Acquired immunodeficiency syndrome (AIDS): precautions for health-care workers and allied professionals. MMWR Morb Mortal Wkly Rep 1983;32(34):450-1.

[25] Garner JS. Hospital Infection Control Practices Advisory Committee. Guideline for isolation precautions in hospitals. Infect Hosp Epidemiol 1996; $17: 53-80$

[26] Spire B, Barre-Sinoussi F, Montagnier L, Chermann JC. Inactivation of lymphadenopathy associated virus by chemical disinfectants. Lancet 1984;2(8408):899901.

[27] Martin LS, McDougal JS, Loskoski SL. Disinfection and inactivation of the human $\mathrm{T}$ lymphotropic virus type III/Lymphadenopathy-associated virus. J Infect Dis 1985;152(2):400-3.

[28] McDougal JS, Martin LS, Cort SP, Mozen M, Heldebrant CM, Evatt BL. Thermal inactivation of the acquired immunodeficiency syndrome virus, human $\mathrm{T}$ lymphotropic virus-III/lymphadenopathy-associated virus, with special reference to antihemophilic factor. J Clin Invest 1985;76(2):875-7.

[29] Olowu O, Oluaje E, Kehinde O. Knowledge and practice of universal precautions among final year medical and dental students in the University College of Ibadan. Dokita 2001;28:6-9.

[30] Odujurin OM, Adegoke OA. AIDS: Awareness and blood handling practices of health care workers in Lagos. Nig J Epidl 1995;11(4):425-30.

[31] Palenick C. Strategic planning for infection control. J Canadian Dental Association 2000;66:556-7.

[32] Danchaivijitr S, Tantiwatanapaiboon Y, Chokloikaew $\mathrm{S}$, et al. Universal precautions: knowledge, compliance and attitudes of doctors and nurses in Thailand. J Med Assoc Thai 1995;78 Suppl 2:S112S117.

[33] Twitchell K. Bloodborne pathogens: what you need to know-Part I. Journal of the American Association of Occupational Health Nurses 2003;51:46-7.

[34] Godin G, Naccache H, Morel S, Ebacher MF. Determinants of nurses' adherence to universal precautions for venipunctures. Am J Infect Control 2000;28(5):359-64.

[35] Stein AD, Makarawo TP, Ahmad MFR. A survey of doctors' and nurses' knowledge, attitudes and compliance with infection control guidelines in Birmingham teaching hospitals. Journal of Infection Control 2003;54:68-73.

[36] Trim JC, Adams D, Elliott TS. Healthcare workers' knowledge of inoculation injuries and glove use. $\mathrm{Br} \mathbf{J}$ Nurs 2003;12(4):215-21.

[37] Rana JS, Khan AR, Haleem AA, et al. Hepatitis C: knowledge, attitudes and practices among orthopedic trainee surgeons in Pakistan. Ann Saudi Med 2000;20(5-6):477-9.

[38] Wang H, Fennie K, He G, et al. A training programme for prevention of occupational exposure to bloodborne pathogens: impact on knowledge, behaviour and incidence of needle stick injuries among student nurses in Changsha, People's Republic of China. J Adv Nurs 2003;41(2):187-94.

[39] Heinrich J. Occupational Safety: Selected cost and benefit implications of needle stick prevention devices for hospitals (letter to House of Representatives from US General Accounting Office), 2000.

[40] Gerberding JL. Clinical practice. Occupational exposure to HIV in health care settings. N Engl J Med 2003;348(9):826-

[41] Connington A. Has the point been made? a needlestick hazards awareness survey. Safe Gard Medical 2002.

[42] Alam M. Knowledge, attitude and practices among health care workers on needle-stick injuries. Ann Saudi Med 2002;22(5-6):396-9.

[43] Sadoh WE, Fawole AO, Sadoh AE, et al. Practice of universal precautions among healthcare workers. J Natl Med Assoc 2006;98(5):722-6.

[44] Jawaid M, Iqbal M, Shahbaz S. Compliance with standard precautions: a long way ahead. Journal of Public Health 2009;38:85-8.

[45] Evanoff B, Kim L, Mutha S, et al. Compliance with universal precautions among emergency department 
personnel caring for trauma patients. Ann Emerg Med 1999;33(2):160-5.

[46] Gershon RR, Karkashian CD, Grosch JW, et al. Hospital safety climate and its relationship with safe work practices and workplace exposure incidents. Am J Infect Control 2000;28(3):211-21.

[47] Janjua NZ, Razaq M, Chandir S, et al. Poor knowledge-predictor of nonadherence to universal precautions for blood borne pathogens at first level care facilities in Pakistan. BMC Infect Dis 2007;7:81.

[48] Cutter J, Jordan S. Uptake of guidelines to avoid and report exposure to blood and body fluids. J Adv Nurs 2004;46(4):441-52.

[49] Nelsing S, Nielsen TL, Nielsen JO. Noncompliance with universal precautions and the associated risk of mucocutaneous blood exposure among Danish physicians. Infect Control Hosp Epidemiol 1997;18(10):692-8.

[50] Brooks AJ, Phipson M, Potgieter A, et al. Education of the trauma team: video evaluation of the compliance with universal barrier precautions in resuscitation. Eur $\mathbf{J}$ Surg 1999;165(12):1125-8.

[51]Richman G, Dorsey A, Stayer S, Schwartz R. Compliance With Standard Precautions Among Pediatric Anesthesia Providers. The Internet Journal of Anesthesiology 2000 4(4):1-8.

Volume 6 Issue 12, December 2017

www.ijsr.net 